\title{
Synthesis of Hydroxamic Ligands with Transition Metal Complexes, their Biological Activities and Characterization Through Spectroscopic Techniques
}

\author{
Farzana Saleem, Naqeebullah Khan*, Samiullah, Attiq-ur-Rehman, Irshad Ali \\ Department of Chemistry, Faculty of Basic Sciences, University of Balochistan, Quetta. Pakistan
}

\begin{tabular}{ll}
\hline \multicolumn{1}{c}{ Articles Information } & \multicolumn{1}{c}{ Abstract } \\
\hline Received: & New metal complexes including Ni (II), Co (II), Cu (II), Fe (III), Cr (III), Cd (II) \\
11.02 .2020 & and $\mathrm{Zn} \mathrm{(II)} \mathrm{have} \mathrm{been} \mathrm{synthesized} \mathrm{from} \mathrm{parent} \mathrm{ligand} \mathrm{N-methyl} \mathrm{m-}$ \\
Accepted: & nitrobenzohydroxamic acid. The condensation ratio is $2: 1$ of the ligand and \\
18.05 .2020 & metal salt (MX) in methanol. The ligand N-methyl m-nitrobenzohydroxamic has \\
Published: & been prepared by the interaction of N-methylhydroxylamine hydrochloride with \\
04.06 .2020 & m-nitrobenzoyl chloride. The coordination modes and bonding of the ligands \\
& along with its metal complexes have been identified by FT-IR, 1H-NMR and UV- \\
Keywords: & Vis spectroscopic techniques. It has been enumerated by spectroscopic \\
Vancomycin & techniques that the complex is formed via O, O-coordination to metal through \\
Zero-order & the oxygen of carbonyl group and deprotonated hydroxyl group. The \\
Area under curve & antibacterial and antifungal activities of the ligand as well as its complexes have \\
First derivative method & been estimated against two gram negative strains such as Escherichia coli and \\
Spectrophotometric & Salmonella typhi, one gram positive strain Escherichia coli and one fungal \\
& strain yeast. In addition to this the cytotoxicity and antitumor activities have \\
\hline
\end{tabular}

DOI: 10.22401/ANJS.23.2.01

* Corresponding author: naqeebhmd2@gmail.com

\section{Introduction}

Hydroxamic acids (R-CONH-OH) have efficacious biological activities due to which they endured wide variety of interest. Because of high biological activity and low toxicity hydroxamic acid generally react as fungal agents, antibacterial agents, antimalarial drugs, enzyme inhibitors, mineral collectors and growth factors [1, 2]. Moreover the derivates of hydroxamic acids are used for allergic diseases, restorative cancer, malaria, cardiovascular diseases and metal poisoning.

Hydroxamic acids ligands have capability to form chelates with metal ions mainly with transition metals which augment their biological activates. These ligands give bidentate chelates by using their $\mathrm{O}, \mathrm{O}$ donor sites. The ligand is deprotonated in to two anionic structures in which one is single deprotonated (hydroxamato) and the other one is double deprotonated (hydroxamato) [3,4]. There are different methods available for the synthesis of hydroxamic acids in which some are monotonous and very expensive. Generally hydroxamic are synthesized by the interaction of hydroxylamine with carboxylic salts or esters [5]. For hard acids they have significant attraction and in various scientific areas the interactions of these acids with metals have generated special fascination [7]. Moreover they also form complexes with various heavy metal ions such has molybdenum( VI ), zirconium(IV), thorium (IV) and hafnium(IV) [8]. Due to biological, industrial, environmental and pharmaceutical applications, the organometallic compounds have achieved significant engrossment [9]. The role of metal complexes as siderophores is very essential. Siderophores serve as $\mathrm{Fe}$ (III) and these are multidentate ligand [10].

Here our on-going engrossment is in the synthesis, crystal structure, biological activity and characterization of hydroxamic acid ligand $\mathrm{N}$ methyl-m-nitrobenzhydroxami acid and its $\mathrm{Zn}($ II), $\mathrm{Cu}($ II $), \mathrm{Fe}($ III), $\mathrm{Cd}($ II), $\mathrm{Co}$ (II), $\mathrm{Ni}$ (II) and $\mathrm{Cr}($ III) metal complexes. In addition to it the antifungal, antibacterial, cytotoxic and antitumor activities of the synthesized metal complexes have been analyzed.

\section{Experimental Work}

2.1. Materials and methods

All the required materials from Sigma Aldrich were purchased and without more purification were used. The purity of the ligand as well as its metal complexes was ensured through TLC 


\title{
Al-Nahrain Journal of Science
}

\author{
ANJS, Vol.23 (2), June, 2020, pp. 1 - 7
}

techniques. In open capillary tubes the melting points were observed via electro -thermal 9300 melting point digital apparatus. Solid state Infrared spectra of the compounds were analyzed via Perkin-Elmer spectrometer utilizing potassium bromide pellet techniques. Through BRUKER FTNMR $600 \mathrm{MHz} 1 \mathrm{H}$ NMR spectra were determined in CDCl3/DMSO-d6. In dimethyl sulfoxide (DMSOd6) UV spectra of the synthesized compounds were recorded.

\subsection{Synthesis of the ligand}

The ligand was prepared by pouring down $\mathrm{m}^{-}$ nitrobenzoyl chloride $(0.01 \mathrm{~mol})$ drop wise to a stirred cold solution containing sodium hydrogen carbonate $(0.01 \mathrm{~mol})$ and $\mathrm{N}$-methylhydroxylamine hydrochloride $(0.01 \mathrm{~mol})$ and below $40 \mathrm{C}$ for $30 \mathrm{~min}$ the solution was stirred further. After filtration at low pressure the solution was evaporated. The undissolved substances were removed by dissolving the precipitate in boiling ethyl acetate and the crystals were obtained by placing the filtrate overnight in fridge [11]. The synthesis of the ligand is manifested in scheme 1.<smiles>O=C(Cl)c1cccc([N+](=O)[O-])c1</smiles><smiles>CN(O)C(=O)c1cccc([N+](=O)[O-])c1</smiles>

Scheme 1. Synthesis of free ligand

$N$-methyl $m$-nitrobenzohydroxamic acid

\subsection{Synthesis of the complex}

The metal complexes of $\mathrm{N}$-methyl $\mathrm{m}^{-}$ nitrobenzohydroxamic acid were synthesized by dissolving the ligand $(2 \mathrm{mmol})$ in $10 \mathrm{ml}$ methanol and the solution was stirred for 20 minutes. The metal salt $(1 \mathrm{mmol})$ was dissolved in small amount of water and poured down in to the solution of ligand. This solution was reflexed with magnetic stirrer for two hours. Under reduced pressure the solvent was evaporated and in ethanol the product was purified and recrystallized [12]. Synthesis of metal complex is represented in scheme 2 .

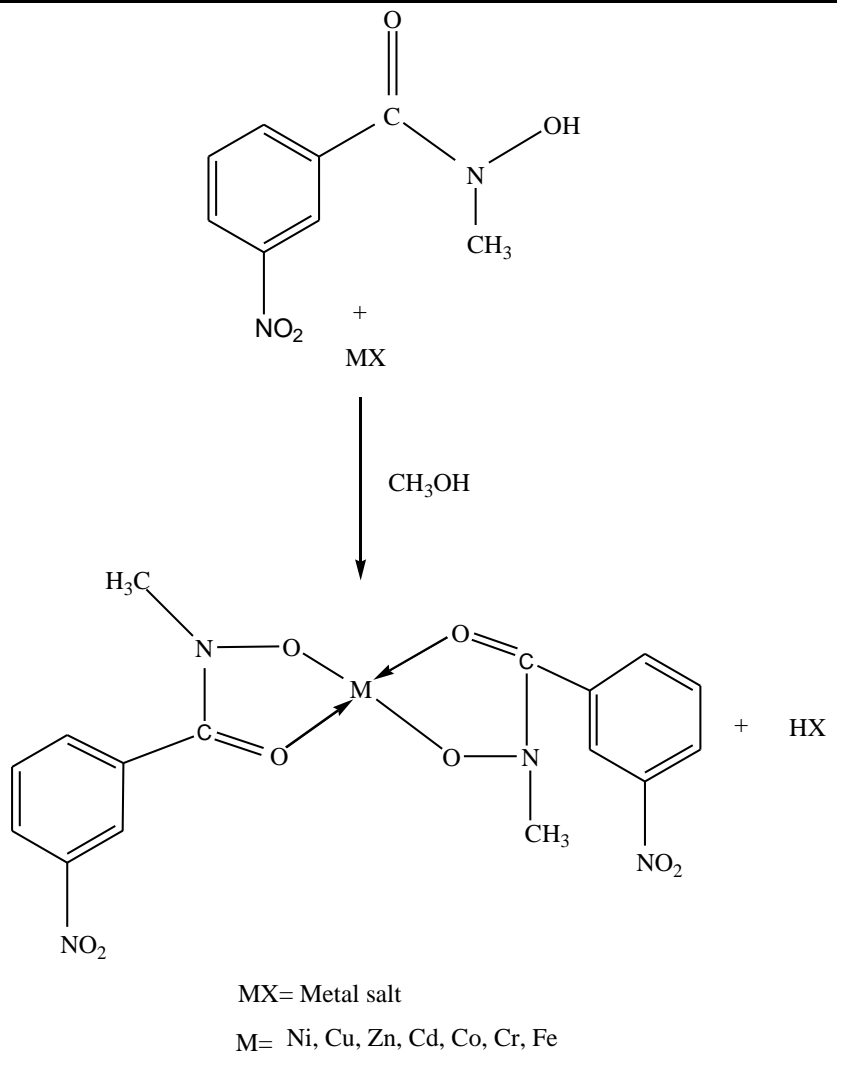

Scheme 2. Synthesis of metal complex of N-methyl m-nitrobenzohydroxamic acid.

\subsection{In-vitro biological activities 2.4.1 Antibacterial assay}

Antibacterial activities of the synthesized compounds were determined through Agar well method against various pathogenic bacterial strains involving Escherichia coli, Staphylococcus aureus and Salmonella typhi. Manufacturer's instructions were followed to prepare Moller Hinton Agar. Agars were sterilized for 15 minutes at $15 \mathrm{lbs}$. After sterilization on 100 millimeter petri plate agar was spread. Bacterial strains for 24 hours were cultured on petri plates having $25 \mathrm{~mL}$ of molten medium. In the medium well $(6$ $\mathrm{mml}$ ) were formed along with sterilized borers as well as $100 \mathrm{ml}$ of stock solutions $(4 \mathrm{mg} / \mathrm{mL}$ in DMSO). In each well the compounds were spilled. The Doxycycline as well as pure DMSO was utilized in the guise of positive and negative pole controls. Then the petri plates for 24 hours were incubated at $370 \mathrm{C}$. The inhibition zone diameter was measured to assay the bactericidal activities of the synthesized ligand and its complexes around every well in $\mathrm{mm}[13,14]$. 


\title{
Al-Nahrain Journal of Science
}

\author{
ANJS, Vol.23 (2), June, 2020, pp. 1 - 7
}

\subsubsection{Antifungal assay}

The antifungal activities were assayed through diffusion method [15]. The fungal strain yeast was obtained from the environment. In dimethyl sulfoxide $(0.02 \mathrm{mg} \backslash 5 \mathrm{ml})$ the solutions of the ligand and complexes were prepared for antifungal activity against yeast. Dextrose agar slants was used to grow the fungal strains. In dextrose agar plates the fungal spores were sabouraudon. The compounds dissolved from 10 to $20 \mathrm{mg}$ concentration so that the fungal cultures in the walls could stay. For 4 day the petri plates incubated and later 5, 8 and 15 days the spores were perceived. Comparing with control the activity and inhibition zone of the ligand and its complexes were measured.

\subsubsection{Brine shrimp lethality assay}

A reported procedure with some improvement was followed in 96 well plate brine shrimp lethality assay versus Artemia salina larvae was analyzed [16]. In a restorative sea water $(37 \mathrm{~g} / \mathrm{L}$ enriched with $5 \mathrm{mg} / \mathrm{L}$ dry yeast), Artemia salina leach eggs (USA, Ocean star) for $24-48 \mathrm{~h}$ at 30 to $320 \mathrm{C}$ in light were hatched in a plastic try particularly manufactured containing two parts. Getting the assistance of Pasteur pipette ten adult phototropic nauplii in each dish were shifted. The out coming volume of every extract containing $<1 \%$ Dimethyl sulfoxide in sea water with 500 and $200 \mu \mathrm{L} / \mathrm{ml}$ concentration was added in the wells having sea water and shrimp larvae. In every one well the terminal volume was kept $100 \mu \mathrm{L} / \mathrm{ml}$. The serial concentrations of positive and negative control well contained 1\% DMSO and etoposide respectively. Later on $24 \mathrm{~h}$ incubation by enumerating live shrimp larvae the death percentage was ascertained. Utilizing table curve software 2D v5.01, average mortality percentage was computed.

\subsubsection{MTT Cytotoxicity}

MTT method was used to assay the antitumor activity of the complexes against Hela cells [7]. In 96 well-plate cells had seeded. Its density per well was $5 \times 104$ and were treated for 24 hours at concentrations of $30 \mu \mathrm{M}$ of the complexes in a volume of about $200 \mathrm{~mL}$. After this remedy, in each treated cell $10 \mu \mathrm{L}$ of 0.5 to $1.5 \mathrm{mg}$ MTT was added and at $37 \mathrm{oC}$ for $4 \mathrm{~h}$ incubated further. Later on from every well the medium was chucked before the addition of $200 \mu \mathrm{L}$ DMSO. For full dissolution for $15 \mathrm{~min}$ incubated the plate and was followed with 5 min softly shaking. The absorbance of every well was measured at $570 \mathrm{~nm}$ to assay the cytotoxic effects of metal complexes on Hela cell line. For every concentration mean absorbance was expressed of the absorbance of vehicle control as percentage and plotted against compound concertation [17].

\section{Result and Discussion 3.1 Synthesis}

The ligand was synthesized interaction of $\mathrm{N}$ methylhydroxylamine hydrochloride with $\mathrm{m}^{-}$ nitrobenzoyl chloride. The reaction was carried out in the existence of sodium hydrogen carbonate as a catalyst. All the chemical reagents in the similar ratio by weight were taken. In 2:1 the metal complexes of the ligands were prepared by relaxing the solution with the help of magnetic stirrer for 12 hours in methanol. At low pressure the solvent was evaporated and the product was recrystallized in ethanol. The purity of the prepared ligand as well as its metal complexes ensured by TLC techniques adsorbent was silica gel-G.

\subsection{Spectroscopic studies \\ 3.2.1 Infra-Red spectroscopy}

In solid state the infrared spectra of the ligand $\mathrm{N}$ methyl-m-Nitrobenzhydroxamic along with its metal complexes in the range of 4000-370 $\mathrm{cm}^{-1}$ have been reported. $\mathrm{V}(\mathrm{O}-\mathrm{H}), \mathrm{v}(\mathrm{C}-\mathrm{N}), \mathrm{v}(\mathrm{C}=\mathrm{O}), \mathrm{v}(\mathrm{N}-$ $\mathrm{O})$ are the essential vibrations. In free hydroxamic acid ligand the stretching vibration $\mathrm{v}(\mathrm{O}-\mathrm{H})$ is noticed as a broad peak in the range of $3,119 \mathrm{~cm}^{-1}$ which describes the presence of spacious hydrogen bonding. This intramolecular hydrogen bonding is present between the lone pair on oxygen atom of carbonyl group and hydroxyl group proton. The characteristic absorption $\mathrm{v}(\mathrm{C}=\mathrm{O})$ is perceived at $1640 \mathrm{~cm}^{-1}$ which is low than the ordinary ketonic $\mathrm{v}(\mathrm{C}=\mathrm{O})$ group location at $1700 \mathrm{~cm}^{-1}$. The sharp peaks for $\mathrm{v}(\mathrm{N}-\mathrm{C})$ and $(\mathrm{N}-\mathrm{O})$ are observed at 1442 and 954 respectively [18].

In the vibration spectra of metal complexes of hydroxamic ligands the absence of $\mathrm{v}(\mathrm{O}-\mathrm{H})$ stretching frequency demonstrated the clear distinctions between ligand and its metal complexes. In all the spectra of the metal complexes the v(O-H) peaks are found absent which indicating that proton of $(\mathrm{OH})$ is replaced by metal. Therefore in the complexes ligand exists in deprotonated form [19]. Similarly the frequencies of $(\mathrm{C}=\mathrm{O})$ shift to smaller value in the range 1,628$1619 \mathrm{~cm}^{-1}$ which proves the complex formation. The absence of $(\mathrm{O}-\mathrm{H})$ stretching frequency and the shifting of $(\mathrm{C}=\mathrm{O})$ group to lower vibrational frequency enumerates that in complexes hydroxamic acid exists in the form of bidentate chelating ligand. In addition to this in the spectra 


\section{Al-Nahrain Journal of Science}

ANJS, Vol.23 (2), June, 2020, pp. 1 - 7

of metal complexes the vibrational frequencies of $(\mathrm{N}-\mathrm{O})$ move to higher value appearing at 995-980 $\mathrm{cm}-1$ preventing the chelation via nitrogen atom. A new band in the range of $459-434 \mathrm{~cm}^{-1}$ is also observed which apparently due to (M-O) bond formation [20].

\subsubsection{H-NMR Spectroscopy}

The $1 \mathrm{H}$ NMR spectra are recorded by dissolving the ligand along with its metal complexes in $\mathrm{CDCl} 3$ at room temperature. The free ligand in $1 \mathrm{H}-\mathrm{NMR}$ spectra show absorption at $8.744 \mathrm{ppm}$ which indicates the presence of hydrogen bonding owning to hydroxyl proton. In the spectra of metal complexes the peak of $\mathrm{OH}$ disappeared which specifies that hydroxyl proton is substituted in the complexes and the ligation of metal to the oxygen atom. The methyl group protons attach to the nitrogen atom show a signal at 3.42 did not change in the spectra of metal complexes which confirm that nitrogen atom is not involved in complexation. The signals observed in the range of 7.69-7.44 ppm as multiplet for the aromatic protons of the ligand and multiplet found for the aromatic protons of the complexes at $7.93-7.24 \mathrm{ppm}$.

\subsubsection{UV-visible spectroscopy}

The electronic spectra of ligand along with its complexes in DMSO were recorded. The concentrations were $1.00 \times 10^{-3}$ and $1.00 \times 10^{-4}$ for the ligand and its complexes. The absorption spectrum of the ligand consists of only one band which appears at $310 \mathrm{~nm}$ owing to $\mathrm{n}^{-} \pi^{*}$. The $\mathrm{n}^{-} \pi^{*}$ found in the spectrum of ligand due to presence of lone pair of electron on oxygen atom. The spectra of the complexes consist of two bands 291-303 nm and $560-594 \mathrm{~nm}$. The variation between the spectra of ligand and complexes specifies the complex formation. However the band which appears at 560-594 $\mathrm{nm}$ is owing to $\mathrm{d}-\mathrm{d}$ transition in the d orbitals of metal [21].

\subsection{Biological studies}

\subsubsection{Antibacterial activity}

Antibacterial activities of the synthesized ligand as well as its complexes are assayed via agar well method against three pathogenic bacterial strains. One gram positive strain (Staphylococcus aureus) and two gram negative strains (Escherichia coli and Salmonella typhi) were screened. The values of inhibition zone noticed in $\mathrm{mm}$ and are given in Table 1. The diameters of inhibitions zone below than $10 \mathrm{~mm}$ are considered as weak, $10-16 \mathrm{~mm}$ are moderate and more than 16 are regarded as active. The ligand $\mathrm{N}$-methyl m-nitrobenzohydroxamic acid manifests moderate activity against Escherichia coli and Salmonella typhi and exhibits no activity against Staphylococcus. Due to the $\mathrm{CO}$ and $\mathrm{OH}$ groups the hydroxamic acid shows biological effectiveness. However the antibacterial activity of hydroxamic acid is owing to their reaction with DNA (Deoxyribose nucleic acid) of the bacteria. The antimicrobial result of the complexes show that all the tested complexes manifest antibacterial activity against bacterial strains except $\mathrm{Co}$ (II) which exhibit no activity against gram negative strain (Escherichia coli). Metal complexes have higher value of inhibition zone as compared to the ligand. The activity of the complexes is enhanced because the size of complexes decreases upon chelation of the ligand and the lipophilicity of the metal complexes increase [8].

Table 1. Antibacterial activities of the ligand and its complexes.

\begin{tabular}{llll}
\hline & \multicolumn{3}{l}{ Inhibition zone (mm) } \\
\hline Compounds & E.Coli & $\begin{array}{l}\text { Salmonella } \\
\text { typhi }\end{array}$ & $\begin{array}{l}\text { S. } \\
\text { aureus }\end{array}$ \\
\hline$N$-methyl & 11 & 13 & NA \\
$m$ - & & & \\
nitrobenzohydrox & & & \\
amic acid & & 28 & 29 \\
$\mathrm{C}_{18} \mathrm{H}_{14} \mathrm{~N}_{4} \mathrm{O}_{8} \mathrm{Zn}$ & 26 & 15 & 8 \\
$\mathrm{C}_{18} \mathrm{H}_{14} \mathrm{~N}_{4} \mathrm{O}_{8} \mathrm{Ni}$ & 13 & 15 & 13 \\
$\mathrm{C}_{18} \mathrm{H}_{14} \mathrm{~N}_{4} \mathrm{O}_{8} \mathrm{Cu}$ & 16 & 15 & 14 \\
$\mathrm{C}_{18} \mathrm{H}_{14} \mathrm{~N}_{4} \mathrm{O}_{8} \mathrm{Co}$ & $\mathrm{NA}$ & 14 & \\
\hline
\end{tabular}

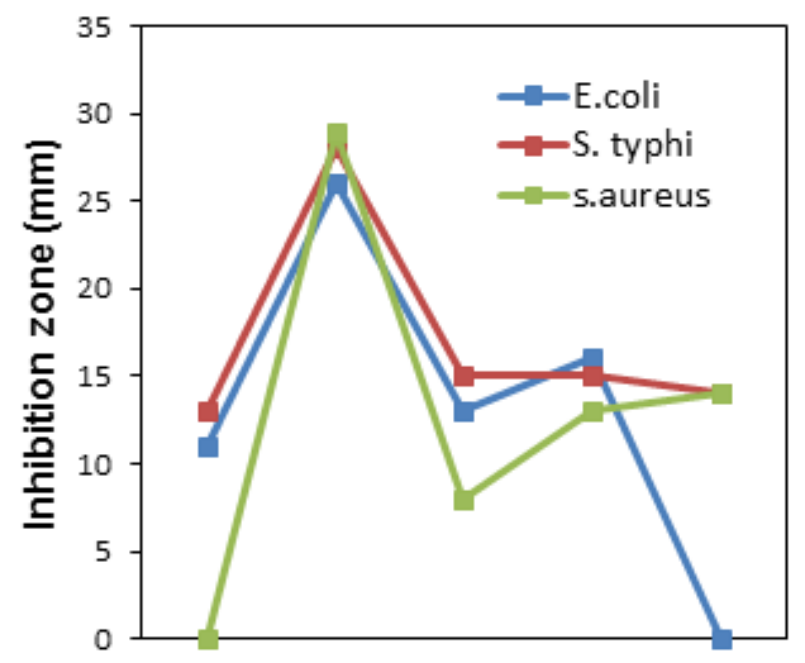

ligand and complexes

Figure 1. Graphical depiction of antibacterial activities of the ligand and its complexes. 


\title{
Al-Nahrain Journal of Science
}

\author{
ANJS, Vol.23 (2), June, 2020, pp. 1 - 7
}

\subsubsection{Antifungal activity}

A diffusion method was used to assay the antifungal activity of the synthesized ligand and its complexes. All the compounds exhibit powerful antifungal activity against Yeast. The antifungal data is given in table 2. These compounds show significant antifungal activity because they can easily penetrate via fungal cell wall. All the compounds showed strong antifungal activity in contrast to antibacterial activity. The antifungal and antibacterial activities of the compounds are different from each other because both fungi and bacteria have different composition of cell structures. The cell wall of bacteria contains cellulose, while the cell wall of fungi bears chitin. In comparison with standard drug these tested compounds inhibit the complete fungal growth [9].

Table 2. Antifungal data of the ligand along with its complexes.

\begin{tabular}{ll}
\hline Inhibition zone $(\mathbf{m m})$ & \\
\hline Compounds & Yeast \\
\hline$N$-methyl & 20 \\
$m$ - nitrobenzohydroxamic & \\
acid & \\
$\mathrm{C}_{18} \mathrm{H}_{14} \mathrm{~N}_{4} \mathrm{O}_{8} \mathrm{Zn}$ & 31 \\
$\mathrm{C}_{18} \mathrm{H}_{14} \mathrm{~N}_{4} \mathrm{O}_{8} \mathrm{Ni}$ & 12 \\
$\mathrm{C}_{18} \mathrm{H}_{14} \mathrm{~N}_{4} \mathrm{O}_{8} \mathrm{Cu}$ & 18 \\
$\mathrm{C}_{18} \mathrm{H}_{14} \mathrm{~N}_{4} \mathrm{O}_{8} \mathrm{Co}$ & 15 \\
\hline
\end{tabular}

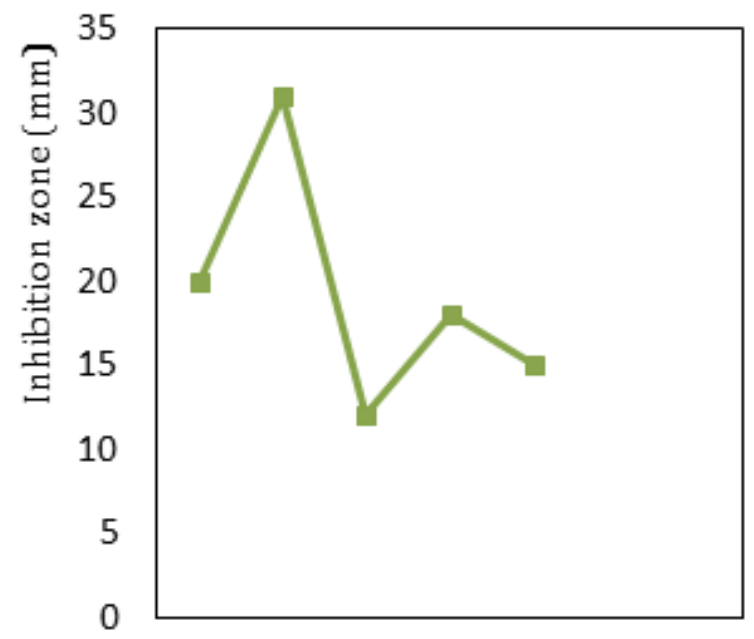

Ligand and complexes

Figure 2. Graphical illustration of antifungal activity of the ligand and its complexes.

\subsubsection{Cytotoxic activity}

Brine shrimp lethality assay was used to evaluate the cytotoxicity activities of the complexes. The complexes of $\mathrm{Zn}($ II ) and $\mathrm{Cu}$ ( II ) were used for cytotoxic activity. The concentrations for the complexes are shown in Table 3. In brine shrimp lethality assay the tested complexes shows no cytotoxicity.

Table 3. Brine shrimp lethality assay of the complexes.

\begin{tabular}{|c|c|c|c|c|}
\hline Complexes & 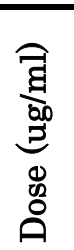 & 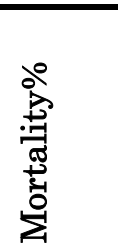 & 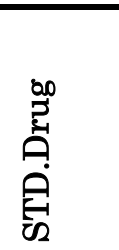 & 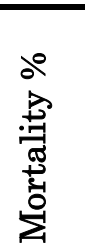 \\
\hline $\mathrm{C}_{18} \mathrm{H}_{14} \mathrm{~N}_{4} \mathrm{O}_{8} \mathrm{Zn}$ & $\begin{array}{l}01 \\
10 \\
100\end{array}$ & $\begin{array}{l}0 \% \\
6.66 \% \\
6.66 \%\end{array}$ & \multirow[b]{2}{*}{$\begin{array}{l}\text { Etopo } \\
\text { side }\end{array}$} & \multirow[b]{2}{*}{$70 \%$} \\
\hline $\mathrm{C}_{18} \mathrm{H}_{14} \mathrm{~N}_{4} \mathrm{O}_{8} \mathrm{Cu}$ & $\begin{array}{l}01 \\
10 \\
100\end{array}$ & $\begin{array}{l}3.3 \% \\
10 \% \\
20 \%\end{array}$ & & \\
\hline
\end{tabular}

\subsubsection{Antitumor activity in vitro}

The antitumor actives of the synthesized complexes were evaluated against HeLa cell line. The compounds were incubated for 24 hours at concentrations from 25-30. Doxorubicin was utilized as standard. Results are given in Table 4. The complexes exhibit no cytotoxicity on Hela cell line at concentration of $30 \mu \mathrm{M}$. Therefore the tested compounds are inactive against human uterine cervix cancer cell line (Hela).

Table 4. Antitumor activity of the complexes.

\begin{tabular}{llll}
\hline Complexes & $\begin{array}{l}\text { Conc. } \\
(\mu \mathrm{M})\end{array}$ & $\begin{array}{l}\text { \% inhibition } \\
\text { /Stimulation }\end{array}$ & $\begin{array}{l}\text { IC50 } \\
\text { SD }\end{array}$ \\
\hline $\mathrm{C}_{18} \mathrm{H}_{14} \mathrm{~N}_{4} \mathrm{O}_{8} \mathrm{Zn}$ & 30 & -43.6 & Inactive \\
$\mathrm{C}_{18} \mathrm{H}_{14} \mathrm{~N}_{4} \mathrm{O}_{8} \mathrm{Co}$ & 30 & -35.1 & Inactive \\
Doxorubicin & 30 & $101.2 \%$ & $0.9 \pm 0.1$ \\
\hline
\end{tabular}

\section{Conclusions}

In this study, the synthesis of hydroxamic acid ligand and it metal complexes have been reported. The ligand and its metal complexes have been prepared successfully and are characterized through spectroscopic techniques. Infrared data of the complexes indicate the absence of $\mathrm{v}(\mathrm{O}-\mathrm{H})$ band, the stretching frequency of carbonyl group moves to smaller value and the frequency of $\mathrm{v}(\mathrm{N}-\mathrm{O})$ becomes higher suggesting that in the complexes hydroxamic acid behave as a bidentate chelator. In the complexes the ligand is present in deprotonated form, was identified via $1 \mathrm{H}-\mathrm{NMR}$ 


\title{
Al-Nahrain Journal of Science
}

\author{
ANJS, Vol.23 (2), June, 2020, pp. 1 - 7
}

spectra. Besides this through UV-VIS spectroscopic data a difference in the electronic transition of hydroxamic acid and its metal complexes has been observed indicating the formation of complexes. The antibacterial assay and antifungal activity results of the tested compounds are dissimilar from each other this is because both bacteria and fungi have different cell wall structures. Moreover the tested complexes exhibit no cytotoxicity and are inactive against human Hela cells.

\section{Acknowledgement}

The authors acknowledge the Department of Chemistry and Department of Microbiology, University of Balochistan, Quetta, Pakistan, for bolstering this work financially and technically. They owe profound and sincere gratitude to H. E. J University of Karachi for running various chemical tests pertaining to the research.

\section{References}

[1] Hassan, L. R.; Ramasamy, K.; Lim, S. M.; Bahron, H.; Taj Uddin, A.M.; "Synthesis and characterization of benzohydroxamic acid metal complexes and their cytotoxicity study"; Tech. J. 80, 87-94, 2018.

[2] Adiguzel, E.; Yilmaz, F.; Emirik, M.; Ozil, M.; "Synthesis and characterization of two new hydroxamic acids derivatives and their metal complexes. An investigation on the keto/ enol, E/Z and hydroxamate/ hydroximates forms"; J. Molec. Struc., 1127-403, 2017.

[3] Liu, K.; Chang, G.; Yan, H.; Li, Z.; Hong, M.; Niu, M.; "Dimethyl tin(IV)complexes derived from hydroxamic acid and acylhydrazone ligands: Synthesis, DNA/bovine serum albumin interaction and cytotoxicity"; J. Appl. Organometal. Chem. 32, 2018 .

[4] Khan, N.; Farina, Y.; Mun, L. K.; Rajab, N. F.; Awang, N.; "Triorganotin(IV) complexes with $\mathrm{o}^{-}$ substituted arylhydroxamates: Synthesis, spectroscopic characterization, X-ray structures and in vitro cytotoxic activities"; J. Organometal. Chem. 763-764, 26-33, 2014.

[5] Mun, L. K.; Farina, Y.; Khan, N.; Rajab, N. F.; Awang, N.; "Syntheses, spectral characterization, $\mathrm{X}$-ray studies and in vitro cytotoxic activities of triorganotin (IV) derivatives of $\mathrm{p}$-substituted $\mathrm{N}^{-}$ methyl benzyl amine dithiocarbamates"; J. Molec. Struc. 1076, 403-410, 2014.

[6] Gupta, S. P.; Sharma, A.; "The Chemistry of Hydroxamic Acids"; J. Hydrox. Acids, 1-17, 2013.

[7] Jewula, P.; Berthet, J. C.; Chambron, J. C.; Rousselin, Y.; Thuéry, P.; Meyer, M.; "Synthesis and Structural Study of Tetravalent (Zr4+, Hf4+, Ce4+, Th4+, U4+) Metal Complexes with Cyclic Hydroxamic Acids"; Euro. J. Inorg. Chem., 15291541, 2015.
[8] Palanimurugan, A.; Kulandaisamy, A.; "DNA, in vitro antimicrobial/anticancer activities and biocidal based statistical analysis of Schiff base metal complexes derived from salicylalidene-4imino-2,3-dimethyl-1-phenyl-3-pyrazolin-5-one and 2-aminothiazole"; J. Organometal. Chem. 861, 263$274,2018$.

[9] Abs-Elzaher, M. M.; J. Chin. Chem, Soc. 48, 26-35 (2012).

[10] Sedaghat, T.; Tahmasbi, L.; Motamedi, H.; ReyesMartinez, R.; Morales-Morales, D.; "Diorganotin (IV) complexes with furan-2-carbohydrazone derivatives: Synthesis, characterization, crystal structure and antibacterial activity"; J. Coord. Chem. 66, 712-724, 2013.

[11] Farina, Y.; Chan, K.; Mun, L.; Rajab, N.; Ooi, T.; "Diorganotin (IV) derivatives of $\mathrm{N}$-methyl $\mathrm{p}^{-}$ fluorobenzo-hydroxamic acid: Preparation, spectral characterization, X-ray diffraction studies and antitumor activity"; Molecu. 18, 8696-8711, 2013.

[12] Khan, N.; Farina, Y.; Mun, L. K.; Rajab, N. F.; Awang, N.; "Syntheses, spectral characterization, $\mathrm{X}$-ray studies and in vitro cytotoxic activities of triorganotin (IV) derivatives of $\mathrm{p}$-substituted $\mathrm{N}^{-}$ methylbenzylaminedithiocarbamates"; J. Molecu. Struct. 1076, 403-410, 2014.

[13] Akbar, A.; Anal, A. K.; "Zinc oxide nanoparticles loaded active packaging, a challenge study against Salmonella typhimurium and Staphylococcus aureus in ready-to-eat poultry meat"; Food Control 38, 88-95, 2014.

[14] Avila-Sorrosa, A.; Hernández-González, J. I.; Reyes-Arellano, A.; Toscano, R. A.; Reyes-Martínez, R.; Pioquinto-Mendoza, J. R.; Morales-Morales, D.; "Synthesis, structural characterization and biological activity of fluorinated Schiff-bases of the type [C6H4-1-(OH)-3-(CHNArF)]”; J. Molecu. Struct. 1085, 249-257, 2015.

[15] Khan, S.; Nami, S. A.; Siddiqi, K. S.; "Mononuclear indolyldithiocarbamates of $\mathrm{SnCl} 4$ and $\mathrm{R} 2 \mathrm{SnCl} 2$ : Spectroscopic, thermal characterizations and cytotoxicity assays in vitro"; J. Organometal. Chem. 693, 1049-1057, 2008.

[16] Fatima, H.; Khan, K.; Zia, M.; Ur-Rehman, T.; Mirza, B.; Haq, I. U.; "Extraction optimization of medicinally important metabolites from Datura innoxia Mill:: an in vitro biological and phytochemical investigation"; BMC Compl. Alter. Med. 15, 376, 2015.

[17] Khan, N.; Farina, Y.; Mun, L. K.; Rajab, N. F.; Awang, N.; "Syntheses, characterization, X-ray diffraction studies and in vitro antitumor activities of diorganotin (IV) derivatives of bis ( $\mathrm{p}$-SubstitutedN-methylbenzylaminedithiocarbamates)"; Polyhedron 85, 754-760, 2015.

[18] Shahid, K.; Ali, S.; Bhatti, M. H.; Mazhar, M.; Mahmood, S.; Rehman, S.; "Synthesis, characterization and thermal analysis of organotin (IV) derivatives of 4-(N-Maleoyl) butanoate"; Turk. J. Chem. 26, 589-598, 2002. 


\section{Al-Nahrain Journal of Science}

ANJS, Vol.23 (2), June, 2020, pp. 1 - 7

[19] Irshad, A.; Khan, N.; Farina, Y.; Baloch, N.; Ali, A.; Mun, L. K.; Murtaza, G.; "Synthesis, spectroscopic characterization, X-ray diffraction studies and invitro antibacterial activities of diorganotin (IV) derivatives with N-methyl-4- bromo-benzohydroxamic acid"; Inorg. Chimica Acta 469, 280287, 2018.

[20] Raman, N.; Kulandaisamy, A.; Thangaraja, C.; Jeyasubramanian, K.; "Redox and antimicrobial studies of transition metal (II) tetradentate Schiff base complexes"; Trans. Metal Chem. 28, 29-36, 2003.

[21] Murtaza, G.; Rauf, M. K.; Badshah, A.; Ebihara, M.; Said, M.; Gielen, M.; Mirza, B.; "Synthesis, structural characterization and in vitro biological screening of some homoleptic copper (II) complexes with substituted guanidines"; Europ. J. Med. Chem. 48, 26-35, 2012.

[22] Affan, M. A.; Salam, M. A.; Ahmad, F. B.; White, F.; Ali, H. M.; "Organotin (IV) complexes of 2hydroxyacetophenone-N (4)-cyclo-hexyl-thiosemicarbazone (H2dact): Synthesis, spectral characterization, crystal structure and biological studies"; Inorg. Chimica Acta 387, 219-225, 2012.

[23] Lin, J.; Lin, J. L.; Tzeng, W. B.; "Mass analyzed threshold ionization spectroscopy of $\mathrm{N}$-deuterium substituted indoline cation: isotope effect on the electronic transition, ionization and molecular vibration"; Chem. Phys. Lett. 371, 662-669, 2003.
[24] Li, Y.; Liu, J.; Li, Q.; "Mechanisms by which the antitumor compound di-n-butyl-di-(4-chlorobenzohydroxamato) tin (IV) induces apoptosis and the mitochondrial-mediated signaling pathway in human cancer SGC-7901 cells"; Molecu. Carcinogenesis 49, 566-581, 2010.

[25] Nath, M.; Pokharia, S.; Yadav, R.; "Organotin (IV) complexes of amino acids and peptides"; Coord. Chem. Rev. 215, 99-149, 2001.

[26] Khan, S.; Nami, S. A.; Siddiqi, K. S.; "Mononuclear indolyldithiocarbamates of $\mathrm{SnCl} 4$ and $\mathrm{R} 2 \mathrm{SnCl}$ : Spectroscopic, thermal characterizations and cytotoxicity assays in vitro"; J. Organometal. Chem. 693, 1049-1057, 2008.

[27] Labisbal E.; Rodriguez, L.; Sousa-Pedrares, A.; Alonso, M.; Vizoso, A.; Romero, J.; Sousa, A.; "Synthesis, characterisation and X-ray structures of diorganotin (IV) and iron (III) complexes of dianionicterdentate Schiff base ligands"; J. Organomet. Chem. 691, 1321-1332, 2006.

[28] Nagy, E. M.; Sitran, S.; Montopoli, M.; Favaro, M.; Marchiò, L.; Caparrotta, L.; Fregona, D.; "Zinc(II) complexes with dithiocarbamato derivatives Structural characterisation and Sbiological assays on cancerous cell lines"; J. Inorg. Biochem. 117, 131-139, 2012.

[29] Gielen, M.; Handlir, K.; Hollein, M.; De Vos, D.; "Synthesis, characterization and anti-tumour activity of some butyltin (IV) cysteaminates and N,N-dimethyl-cysteaminates"; Met. Based Drugs 7, 233-236, 2000. 